\title{
Short-term effects of organic matter scalping on the growth and nutrition of black spruce and jack pine seedlings planted in the boreal forest
}

\author{
by Nelson Thiffault ${ }^{1}$
}

\begin{abstract}
Scarification contributes to creating planting microsites for reforestation by mixing organic matter (OM) with the upper layers of mineral soil. However, on some boreal sites characterized by a thick humus layer and dominated by ericaceous shrubs, competition seems to limit the benefits of scarification. A potential solution would be to remove OM completely through scalping. The objective of our study was to compare the short-term effects of scarification and scalping on the growth of Picea mariana and Pinus banksiana on such sites. After three growing seasons, we explored the relationships between seedling growth, groups of competing vegetation species, planting depth and distance to the nearest OM accumulation. The two treatments had similar effects on these variables. Growth on plots subjected to scalping was independent from the distance to OM. Planting depth had a nil or positive effect on seedling growth. Pinus seedlings largely outgrew Picea seedlings. However, the lack of short-term difference between scarification and scalping must be interpreted with caution, given the potential mid- and long-term effects of OM exportation on soil fertility, erosion and seedling nutrition.
\end{abstract}

Key words: reforestation, plantation, site preparation, Picea mariana, Pinus banksiana

\section{RÉSUMÉ}

Le scarifiage contribue à créer des microsites pour le reboisement en mélangeant la matière organique (MO) aux couches superficielles de sol minéral. Toutefois, sur certaines stations boréales caractérisées par des humus épais et un couvert dominé par les plantes éricacées, la compétition semble limiter les avantages du scarifiage. Une solution pourrait être d’enlever complètement la MO par décapage. Notre objectif est de comparer, sur une telle station, les effets à court terme du scarifiage et du décapage sur la croissance de plants de Picea mariana et de Pinus banksiana. Après 3 saisons, nous avons exploré les relations entre la croissance des plants et les groupes d'espèces de végétation concurrente, la profondeur de mise en terre et la distance jusquà l'amas de MO le plus proche. Les deux traitements ont eu des effets semblables sur les variables mesurées. La croissance dans les parcelles décapées était indépendante de la distance à la MO. La profondeur de mise en terre a eu un effet nul ou positif sur la croissance des plants. Les plants de Pinus ont poussé beaucoup plus vite que ceux de Picea. L'absence de différence à court terme entre les traitements doit être interprétée avec prudence, compte tenu des effets potentiels à moyen et à long termes de l'exportation de la MO sur les processus nutritionnels et lérosion.

Mots-clés : reboisement, plantation, préparation de terrain, Picea mariana, Pinus banksiana

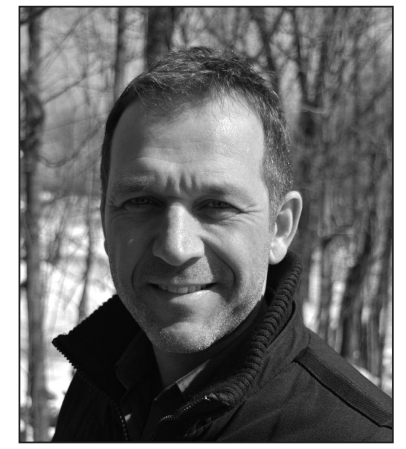

Nelson Thiffault

\section{Introduction}

Maintaining ecosystem productivity is an essential part of sustainable forest management and implies an adequate regeneration of harvested sites after disturbances (Lieffers et al. 2003). When natural regeneration is insufficient, site productivity may be restored by planting to compensate for a poor distribution or insufficient density of natural seedlings (Nyland 2002). The performance of planted seedlings, however, depends on interactions between the planted material (species, stock type and genotype) and environmental conditions (Grossnickle 2012), especially the microenvironment which directly influences resource availability (air and soil temperatures, nutrients, water and light). Low availability of resources causes stress and jeopardizes seedling establishment (Margolis and Brand 1990). To optimize the significant investments devoted to genetic improvement programs, seedling production and planting (Thiffault et al. 2013), reforestation microsites should provide resource levels with values as optimal as possible (Burdett 1990).

However, the specific characteristics of reforestation microsites that minimize planting stress are hard to identify (organic/mineral mix, Salonius 1983; planting depth, Sutton 1995; amount of woody debris, Devine and Harrington 2007). Several studies have documented the effects of scarification on plantation establishment in boreal forests

${ }^{1}$ Direction de la recherche forestière, Ministère des Forêts, de la Faune et des Parcs du Québec, Québec, QC, et Centre détude de la forêt, Université Laval, Québec; email: nelson.thiffault@mffp.gouv.qc.ca 
(e.g., Prévost and Dumais 2003, Hébert et al. 2014, Henneb et al. 2015). Other studies have focused on the management of woody debris and their effects on seedling microenvironment (e.g., Trottier-Picard et al. 2014) or the effect of planting depth on growth (Paquette et al. 2011) and frost heaving (Sahlén and Goulet 2002). However, thick humus layers that accumulate over very long fire cycles (Bouchard et al. 2008, Ward et al. 2014) characterize many mesic sites in Northeastern Quebec (Canada). Moreover, mature boreal stands are characterized by understories dominated by ericaceous shrubs, including Rhododendron groenlandicum (Oeder) Kron and Judd and Kalmia angustifolia L. (Thiffault et al. 2015) that can increase in cover following forest harvesting (Thiffault and Grondin 2003). In such restrictive conditions, trenching scarification is sometimes not effective in creating adequate microsites. Indeed, ericaceous shrub litter is rich in phenolic compounds that hamper the growth of conifers, directly and indirectly (Bradley et al. 1997, Inderjit and Mallik 1999, LeBel et al. 2008). Although trenching results in warmer soil temperatures and increases organic matter decomposition (Prévost 1992), the properties of the forest humus associated with ericaceous shrubs could limit the benefits expected from mixing humus with the mineral soil through scarification. Also, considering that even a relatively low Kalmia cover can significantly hamper initial conifer growth (Thiffault et al. 2005), planting microsites should provide planted seedlings with the largest possible area free of the impact of this species (Thiffault et al. 2012). Therefore, the effectiveness of trenching in creating productive microsites can be limited when forest humus layers are thick (Henneb et al. 2015). More radical methods such as forest harrowing might be considered, but the regional availability of specialized equipment, the presence of thin soils or high levels of stoniness can restrict the use of this method (Gravel et al. 2015).

Scalping organic matter is generally not recommended as a silvicultural tool (Prévost and Thiffault 2013) since the entire removal of forest humus deprives microsites of a major nutrient capital (Munson et al. 1993, Prescott et al. 2000). Exposed mineral soil is also subjected to temperature variations greater than soil covered by a humus layer with insulating properties (Prévost 1992). Such variations can cause seedling frost heaving (Goulet 2000), particularly in soils with a high clay content. In addition, temperature increases in a soil exposed by scalping can reduce its water content and cause major hydric stress to seedlings. Such impacts have been observed on a recently harvested site in Northwestern Quebec, characterized by an $8 \mathrm{~cm}$-thick humus and a Kalmia, Vaccinium spp. and Cladonia spp. cover (Thiffault et al. 2004). Nonetheless, some silviculturists argue that the complete removal of humus might sometimes yield benefits, for instance in areas characterized by abundant annual rainfall and fewer risks of water stress. The benefits of creating an environment free of the influence of ericaceous shrubs or their related humus could likely offset the adverse effects of the treatment. Few studies have addressed the effects of complete scalping of organic matter in such conditions, which differ from winter removal of woody debris on frozen soils where a certain thickness of organic matter is maintained above the mineral soil layer. Most research on this topic has been conducted in mixed or hardwood forest ecosystems (e.g., Frey et al. 2003, Newmaster et al. 2007, Gradowski et al.
2008, Lazaruk et al. 2008, Dumas 2012) with treatments limited to a few square meters. By eliminating the organic matter layer, scalping could actually reproduce the impact of highintensity fires in the boreal forest and, to some extent, be part of an ecosystem-based management strategy (Gauthier et al. 2008). However, forest fires usually do not eliminate organic matter entirely; Greene et al. (2007) reported an average reduction of $60 \%$ after studying 14 forest fires across Canada.

The objective of our study was to determine the shortterm effects of organic matter scalping down to the first mineral horizon on the nutrition and growth of conifer seedlings planted on a site located in the North Shore region of Quebec, dominated by Kalmia and characterized by a thick layer of organic matter. We verified the hypothesis that organic matter incorporated into mineral soil through standard disk scarification is a short-term source of nutrients for planted seedlings and that it imparts microsites with characteristics conducive to initial seedling growth, including reduced ericaceous coverage. Based on this hypothesis, we predicted that the complete removal of forest humus through mechanical scalping would create microsites more nutrient deficient than those created through disk scarification. Lower leaf nutrient concentrations and stunted planted seedling growth on scalped plots should reflect such a prediction. On the same plots, we also predicted that seedlings would grow more slowly if their distance from the nearest windrow (their main source of nutrients, McCavour et al. 2014) was greater and that planting depth would play a significant and positive role in growth. To verify these predictions, we established an operational-level experiment that included two site preparation treatments prior to planting black spruce (Picea mariana [Mill.] BSP) and jack pine (Pinus banksiana L.) seedlings. These two species are known for their distinct efficiency in absorbing and using nutrients (Reich et al. 1998a).

\section{Materials and Methods \\ Experimental Site and Design}

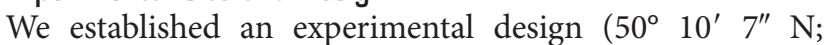
$68^{\circ} 44^{\prime} 57^{\prime \prime} \mathrm{W}$ ) in the black spruce-feather moss bioclimatic domain of Quebec (Saucier et al. 2009), about $120 \mathrm{~km}$ northwest of Baie-Comeau, Quebec. The site is located on a till deposit more than one metre thick, where a podzolic soil developed (Soil Classification Working Group 1998). The soil has a sandy loam texture (74\% sand, $18 \%$ loam, $8 \%$ clay) and mesic-to-subhydric drainage. The original stand was mainly dominated by black spruce with an understory dominated by Kalmia. The stand was harvested in 2010 with protection of regeneration and soils.

In September 2011, we delimited four experimental blocks of $60 \times 50 \mathrm{~m}$, each divided into two main plots of $25 \times 50 \mathrm{~m}$ separated by a 10 -m buffer strip. In each block, two site preparation treatments were assigned randomly to the plots: ( $i)$ disk trenching scarification or (ii) complete scalping of the forest humus down to the first mineral horizon. Scarification was performed with a T26 scarifier (Bracke Forest AB, Bräcke, Sweden). It produced straight trenches, each 2-m apart, $67 \mathrm{~cm} \pm 18 \mathrm{~cm}$ (mean \pm standard deviation) wide, $39 \mathrm{~cm} \pm 12 \mathrm{~cm}$ deep and lined with an organic matter heap mixed with mineral soil. Scalping used a D7H bulldozer (Caterpillar, Peoria, Illinois). Organic horizons were scalped and piled in windrows $1 \mathrm{~m}$ to $2 \mathrm{~m}$ high at the edge of the plots. 
The experimental design did not include any control plots (not treated with site preparation) since many studies have shown the importance of site preparation to ensure the survival and initial growth of seedlings planted on boreal sites dominated by ericaceous shrubs (e.g., Prévost and Dumais 2003, Thiffault and Jobidon 2006).

In June 2012, we divided each main plot into two subplots of $25 \times 25 \mathrm{~m}$ to which we assigned species for planting, black spruce or jack pine. Seedlings were from local seed sources and grown in containers of 45 cavities of $110 \mathrm{~cm}^{3}$ each. A randomly selected sample of 50 seedlings of each species was set aside before planting for planting stock characterization. The height and biomass of jack pine were superior to those of black spruce (except for twigs), but foliar nutrient concentrations were higher in black spruce (Table 1).

In each subplot, seedlings were planted based on a spacing grid of about $2.5 \times 2.0 \mathrm{~m}$. In scarified plots, seedlings were planted between the shoulder and the bottom of trenches. At the centre of each subplot, an 8-m radius circular sampling plot was established to include an average of 35 seedlings to measure per experimental unit (563 seedlings for the entire experiment).

\section{Seedling and Vegetation Measurement}

After planting, seedlings located in the circular sampling plots were identified with a metal rod marker and a sequential number. Their initial height $(\mathrm{cm})$, ground-level diameter $(\mathrm{mm})$, distance from the nearest ericaceous shrub (up to $150 \mathrm{~cm}$ ) and planting depth were measured. Planting depth was defined as the vertical distance between the top of the peat root plug and soil level. A negative value means that the plug was inserted under the surface of the soil, while a positive value means that the plug was not completely buried. For each numbered seedling planted in the scalped plots, the distance between its base and the nearest organic matter heap (in most cases, the windrow) was measured.

In July 2014 (third growing season after planting), we surveyed competing vegetation growing within a $50-\mathrm{cm}$ radius from each seedling. We visually assessed the proportion of plant cover (by $5 \%$ classes) using the following functional groups: trees, grass, moss, ericaceous shrubs, broad-leaved plants, woody shrubs, sphagnum, ferns and alder. The distance between the planted seedlings and the nearest ericaceous shrub individual was recorded up to $150 \mathrm{~cm}$. In October 2014, at the end of the third growing season, the height and ground-level diameter of all the planted trees were measured once more.

\section{Chemical Analyses}

In October 2014, we randomly selected three seedlings in each experimental unit. We harvested a foliar sample from the current year in the upper third of their crown and a soil sample within a $10-\mathrm{cm}$ radius from their base. Soil samples were collected to represent the seedling root environment, i.e., at a depth corresponding to plug position. Samples were kept cool until further manipulation. Foliar samples were dried at $65{ }^{\circ} \mathrm{C}$ for 48 hours and ground for one minute (Pulverisette 0 , Fritsch, Idar-Oberstein, Germany). Soil samples were dried at room temperature and then ground to $2 \mathrm{~mm}$. $\mathrm{C}$ and $\mathrm{N}$ concentrations were determined through combustion at $1350{ }^{\circ} \mathrm{C}$ using a TruMac CN Elemental Analyzer (LECO Corporation, St-Joseph, MI, USA) on $300 \mathrm{mg}$ samples of tissue and $500 \mathrm{mg}$ of soil. $\mathrm{P}$ and $\mathrm{K}$ concentrations of leaf tissue were determined through plasma atomic emission spectrometry (ICAP $61^{\mathrm{E}}$, ThermoInstruments, Franklin, MA) following $\mathrm{H}_{2} \mathrm{SO}_{4}+\mathrm{H}_{2} \mathrm{O}_{2}$ digestion of $100 \mathrm{mg}$ samples (Walinga et al. 1995). Soil samples ( $3.0 \mathrm{~g}$ ) were subjected to a Mehlich III extraction before plasma atomic emission spectrometry analysis (Carter 1993).

\section{Statistical Analyses}

Using June 2012 and October 2014 seedling dimensions, we calculated absolute growth (dimensions in October 2014 - dimensions in June 2012) and relative growth rate over three growing seasons:

$$
R G R=\frac{\ln X_{F 2014}-\ln X_{S 2012}}{3}
$$

Where $R G R=$ Relative growth rate $X=$ Height or ground-level diameter F2014 = Measure taken in October (fall) 2014 S2012 = Measure taken in June (spring) 2012

All analyses were performed using R v3.0.2 (R Core Team 2013). Height (fall 2014), diameter (fall 2014), absolute growth and relative growth data as well as foliar and soil nutrient concentration data (fall 2014) were submitted to analyses of variance (ANOVA) for mixed models using the lme function of the lme4 package (Bates et al. 2015). Blocks and block interactions were considered as random effects; site preparation treatment, species and the site preparation $x$ species interaction were included as fixed effects. The per- 
Table 2. Results from analyses of variance (fixed effects) on black spruce and jack pine seedling dimensions and growth following two site preparation treatments (disk scarification or scalping of the organic matter]

\begin{tabular}{|c|c|c|c|c|c|c|}
\hline \multirow[b]{2}{*}{ Variable } & \multicolumn{2}{|c|}{$\begin{array}{c}\text { Site } \\
\text { preparation }\end{array}$} & \multicolumn{2}{|c|}{ Species } & \multicolumn{2}{|c|}{$\begin{array}{c}\text { Site preparation } \\
\times \text { species }\end{array}$} \\
\hline & $\mathbf{F}$ & $p$ & $\mathbf{F}$ & $p$ & $\mathbf{F}$ & $p$ \\
\hline Height after 3 growing seasons & 1.70 & 0.284 & 123.98 & $<0.001$ & 0.55 & 0.486 \\
\hline Absolute height growth & 1.14 & 0.364 & 209.10 & $<0.001$ & 0.65 & 0.452 \\
\hline Relative height growth rate & 0.13 & 0.742 & 576.03 & $<0.001$ & 4.95 & 0.068 \\
\hline Diameter after 3 growing seasons & 4.37 & 0.128 & 111.05 & $<0.001$ & 2.85 & 0.142 \\
\hline Absolute diameter growth & 4.15 & 0.134 & 117.09 & $<0.001$ & 3.45 & 0.113 \\
\hline Relative diameter growth rate & 2.09 & 0.244 & 158.47 & $<0.001$ & 3.00 & 0.134 \\
\hline
\end{tabular}

jack pine and $25.7 \mathrm{~cm}$ $\pm 1.5 \mathrm{~cm}$ for black spruce. During the same period, the absolute diameter growth was $11.6 \mathrm{~mm} \pm 0.4 \mathrm{~mm}$ for jack pine and $5.7 \mathrm{~mm}$ $\pm 0.4 \mathrm{~mm}$ for black spruce. The relative growth rates reflected the same trend (data not presented).

\section{Competing Vegetation}

Among all the groups of plant species, only grass, moss, ericaceous shrubs and broad-leaved plants were present in the immediate environment of the

cent cover of various groups of species was transformed using the inverse sine of the square root before being submitted to mixed model ANOVAs, with site preparation as the sole fixed effect. Data on the distance between planted seedlings and the nearest ericaceous shrubs were analyzed with a simple linear model for truncated data (Tobit model) using the $\mathrm{vglm}$ function of the VGAM package (Yee 2008). We used the $l m$ function of the car package (Fox and Weisberg 2011) to perform linear regressions between planting depth and relative growth rates based on height and diameter. For seedlings planted in scalped plots, we also produced regressions between the relative growth rate and distance between seedlings and the nearest windrow.

To explore correlations between variables describing microsite characteristics and seedling response in terms of nutrient and growth, we submitted foliar nutrient, vegetation percent cover, relative height growth and soil characteristic data to principal component analyses using the PCA function of the FactoMineR package using correlation matrix (Lê et al. 2008). Data on the two species were analyzed separately. For each analysis, we restricted our interpretation to axes showing eigenvalues $>1$. In addition, we only included the percent cover data of vegetation groups showing $>0 \%$ values in at least one of the treatments.

\section{Results \\ Height and Diameter Growth}

Survival of planted seedlings was very high. Among the planted trees, only two died at the end of the three-year monitoring period, a jack pine in a scalped plot and a black spruce in a scarified plot. We did not identify any significant effect of site preparation on height, diameter, absolute growth rate and relative growth rate in seedlings of the two species $(p \geq 0.128$; Table 2). However, differences between the two species were significant for all these variables (all the $p<0.001$ ), regardless of treatment (site preparation $\times$ species, $p \geq 0.068$; Table 2 ). After three growing seasons, jack pine showed an average height of $58.4 \mathrm{~cm} \pm 1.5 \mathrm{~cm}$ (mean \pm standard error) and an average diameter of $15 \mathrm{~mm} \pm 0.5 \mathrm{~mm}$. Black spruce reached an average height of $40.2 \mathrm{~cm} \pm 1.5 \mathrm{~cm}$ and an average diameter of $8.7 \mathrm{~mm} \pm 0.5 \mathrm{~mm}$. These dimensions were the results of three years absolute height growth of $48.5 \mathrm{~cm} \pm 1.5 \mathrm{~cm}$ for seedlings. Grass and moss percent covers (average values of $2 \%$ and $15 \%$, respectively) were equivalent in scalped and scarified plots $\left(\mathrm{F}_{1,3} \leq 0.98, p \geq 0.395\right)$. Scalping significantly reduced the proportion of ericaceous shrub cover from $12 \%$ to $1 \%$, compared with disk scarification $\left(\mathrm{F}_{1,3}=118.8\right.$, $p=0.002)$. Scalping also reduced the percent cover of broadleaved plants compared with scarification $\left(\mathrm{F}_{1,3}=13.5\right.$, $p=0.035$ ), with respective values of $0 \%$ and $3 \%$ for the two treatments. On most scalped plot microsites, the ericaceous shrub nearest to the planted seedlings at the time of planting was located more than $150 \mathrm{~cm}$ away (Fig. 1a). Conversely, the distribution of seedling-ericaceous shrub distance in scarified plots was unimodal with an average of $56 \mathrm{~cm}$ (Fig. 1a). The Tobit model revealed that the predicted distance value at the time of planting was $120 \mathrm{~cm}$ shorter in scarified plots than in scalped plots $(Z=-24.6, p<0.001)$. Overall, the effect of site preparation on the distance was strongly significant $(p<$ 0.001). After three growing seasons, we observed that the frequency of the " $150-\mathrm{cm}$ " truncating value in scalped plots remained much higher than expected compared with the rest of the distribution (Fig. 1b). An average of $31 \mathrm{~cm}$ in distance values was recorded in scarified plots, with no occurrences of the truncating value (Fig. 1b). The predicted distance value after three growing seasons was $64 \mathrm{~cm}$ shorter in the scarified plots than in the scalped plots $(Z=-17.5, p<0.001)$. After three growing seasons, the effect of site preparation on the distance between the planted seedlings and the nearest ericaceous shrubs was still highly significant $(p<0.001)$.

\section{Soil and Foliar Nutrient Concentrations}

In October 2014, soil nutrient concentrations did not differ significantly among the site preparation treatments $\left(\mathrm{F}_{1,3} \leq 1.02, p \geq 0.386\right)$ or the species $\left(\mathrm{F}_{1,6} \leq 1.74, p \geq 0.235\right)$. Similarly, we did not detect any significant differences in seedling foliar N, P and $\mathrm{K}$ concentrations measured in October 2014, whether in the scarified or scalped plots $\left(F_{1,3} \leq 8.23\right.$, $p \geq 0.064)$. However, the species significantly influenced foliar $\mathrm{P}\left(\mathrm{F}_{1,6}=53.86, p<0.001\right)$ and $\mathrm{K}\left(\mathrm{F}_{1,6}=14.27, p=0.009\right)$ concentrations, with black spruce with higher foliar $\mathrm{P}$ and $\mathrm{K}$ concentrations than jack pine (P: $2.2 \pm 0.07 v s .1 .4 \pm 0.07 \mathrm{~g} / \mathrm{kg}$; $\mathrm{K}: 6.3 \pm 0.2$ vs. $5.2 \pm 0.2 \mathrm{~g} / \mathrm{kg})$. 

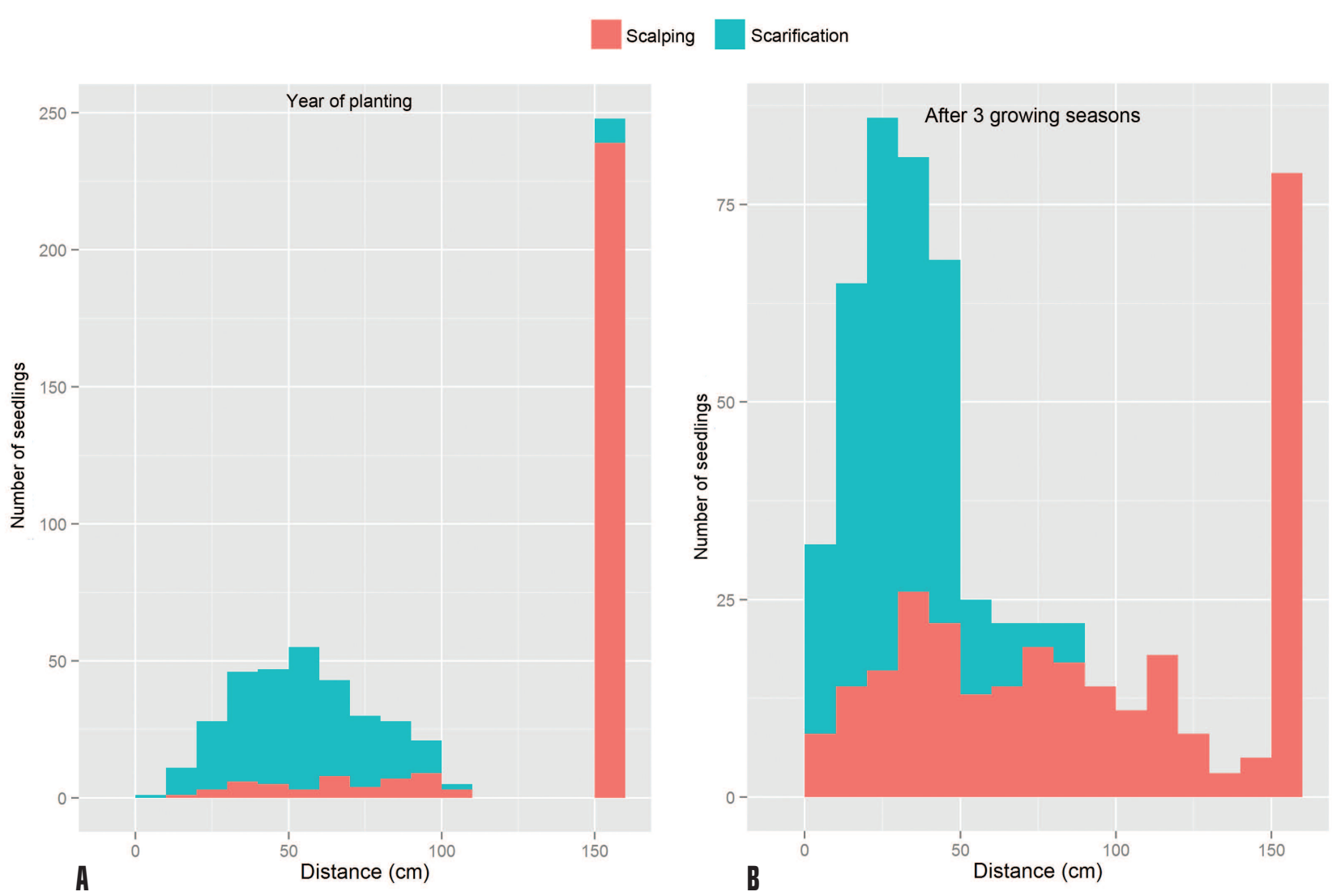

Fig. 1. Distribution of seedling number based on distance to nearest ericaceous shrub at planting (A) and after three growing seasons (B).

Planting Depth and Distance from the Nearest Windrow

For black spruce, planting depth varied from $-8 \mathrm{~cm}$ to $5 \mathrm{~cm}$ but did not have any significant effect on the relative height and diameter growth rates of seedlings in the scalped plots ( $p \geq 0.098$; Fig. 2a and 2b). However, it had a significant $(p \leq 0.011)$ yet low $\left(R^{2} \leq 0.089\right)$ effect for this species in plots prepared with disk scarification; relative height (Fig. 2a) and diameter (Fig. 2b) growth rates increased with planting depth. For jack pine, we observed a significant relationship $(p<0.001)$ between planting depth and the relative height growth rate in both scalped and scarified plots (Fig. 2c). The diameter growth of jack pine was not influenced by planting depth ( $p \geq 0.123$; Fig. $2 d$ ).

For seedlings in scalped plots, we did not detect any significant effect $(p \geq 0.142)$ of the distance between planting spot and nearest organic matter heap on relative height (Fig. 3a) and diameter (Fig. 3b) growth rates of both black spruce and jack pine.

\section{Principal Component Analyses}

For black spruce, the four first axes derived from the principal component analysis with eigenvalues $>1$ together accounted for $79.7 \%$ of the matrix variance. Soil $\mathrm{C}$ concentration $(\operatorname{Cos} 2=0.877 ; C T R=27.11)$, with soil cation exchange capacity $(\operatorname{Cos} 2=0.817 ; C T R=25.26)$ and soil $\mathrm{N}$ concentration $(\operatorname{Cos} 2=0.790$; CTR $=24.42)$ were the variables best represented by the first axis (eigenvalue $=3.235$; Fig. $4 \mathrm{a}$ ). The sec- ond axis (eigenvalue $=2.364$; Fig. 4a) appropriately represented the proportion of broad-leaved plant cover $(\operatorname{Cos} 2=0.442 ; C T R=18.68)$, grass $(\operatorname{Cos} 2=0.393 ;$ $C T R=16.62)$ and ericaceous shrubs $(\operatorname{Cos} 2=0.385$; $C T R=16.28)$ and soil $\mathrm{P}$ concentration $(\operatorname{Cos} 2=0.316$; $C T R=16.36$ ). The third axis (eigenvalue $=2.02$; proportion of variance explained $=15.5$; not presented) was primarily associated with foliar $\mathrm{N}$ concentration $(\operatorname{Cos} 2=0.664$; $C T R=32.90$; coordinate $=-0.815$ ), relative height growth rate $(\operatorname{Cos} 2=0.373 ; C T R=18.47$; coordinate $=0.611)$ and moss percent cover $(\operatorname{Cos} 2=0.346$; CTR $=17.15$; coordinate $=0.589$ ). Lastly, the fourth axis (eigenvalue $=1.689$; proportion of variance explained $=13.0$; not presented) primarily represented soil $\mathrm{P}(\operatorname{Cos} 2=0.456 ; C T R=27.02$; coordinate $=0.676)$ and $\mathrm{K}(\operatorname{Cos} 2=0.370$; CTR $=21.91$; coordinate $=0.608)$ concentrations. When represented in the space formed by the two first axes (Fig. $4 \mathrm{~b}$ ), scarification and scalping observations presented an incomplete separation of the treatments with an overlapping of the 95\% confidence ellipses. Scalped plot observations were associated with higher soil $\mathrm{N}$ and $\mathrm{C}$ concentrations and CEC values than those associated with scarified plot observations, whereas scarified plot observations were associated with higher soil base cation concentrations than those associated with scalped plot observations.

For jack pine, three axes with eigenvalues $>1$ were identified through the principal component analysis of data. 

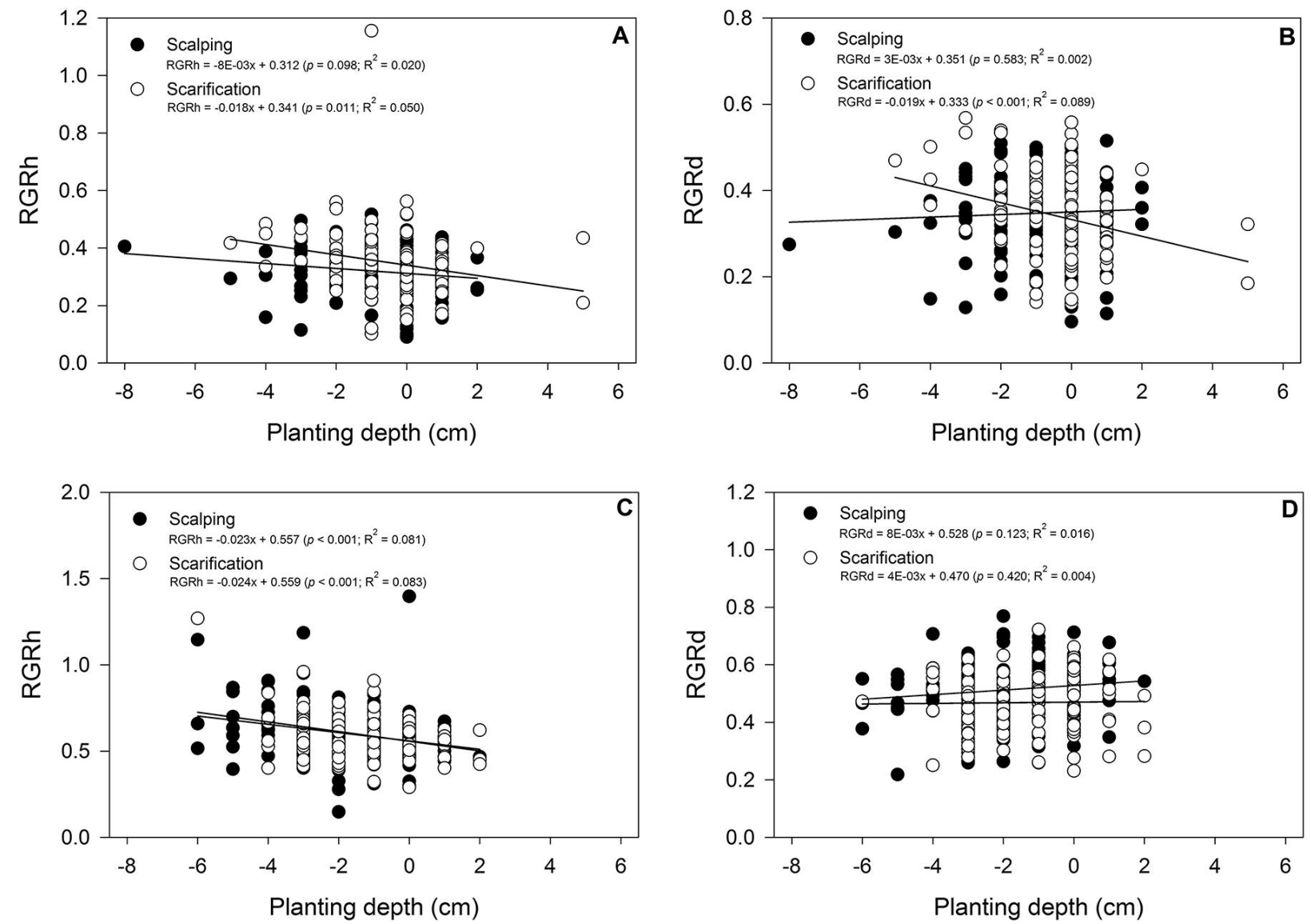

Fig. 2. Relationship between planting depth and relative height (RGRh; $\boldsymbol{A}$ and $\mathbf{C}$ ) and diameter (RGRd; B and D) growth rates for black spruce ( $\boldsymbol{A}$ and $\mathbf{B}$ ) and jack pine ( $\mathbf{C}$ and $\mathbf{D}$ ). Depth is the distance between top of peat root plug and soil surface at planting. A negative value implies that the plug was planted below soil surface; a positive value implies that the plug was not entirely buried underground.

Together, the axes accounted for $71.6 \%$ of the matrix variance. The first axis (eigenvalue $=4.089$; Fig. 5a) was strongly associated with soil $\mathrm{C}(\operatorname{Cos} 2=0.653 ; C T R=15.97)$ and $\mathrm{N}$ $(\operatorname{Cos} 2=0.583 ; C T R=14.25)$ concentrations, the percent cover of ericaceous shrubs $(\operatorname{Cos} 2=0.536 ; C T R=13.10)$ and cation exchange capacity $(\operatorname{Cos} 2=0.443 ; C T R=10.83)$. The second axis (eigenvalue $=3.179$; Fig. 5a) primarily captured the variance associated with foliar $\mathrm{P}(\operatorname{Cos} 2=0.691$; $C T R=21.75), \mathrm{N}(\operatorname{Cos} 2=0.609 ; C T R=19.16)$ and $\mathrm{K}$ $(\operatorname{Cos} 2=0.526 ; C T R=16.53)$ concentrations. Lastly, the third axis (eigenvalue $=2.04$; proportion of variance explained $=15.7$; not presented) appeared to be primarily associated with the percent cover of broad-leaved plant $(\operatorname{Cos} 2=0.395 ; C T R=19.35$; coordinate $=0.628)$ and ericaceous shrubs $(\operatorname{Cos} 2=0.285 ; C T R=13.97$; coordinate $=0.534)$ and the cation exchange capacity of soil $(\operatorname{Cos} 2=0.272$; $C T R=13.35$; coordinate $=-0.522$ ). The distribution of scalping and scarification observations in the space defined by the first two axes (Fig. 5b) showed significant overlapping. The averages of observation coordinates for each treatment were included in the $95 \%$ confidence interval of the other treatment.

\section{Discussion}

Overall, disk scarification and organic matter scalping treatments had similar short-term effects on soil and foliar nutrient concentrations. The same applied to black spruce and jack pine growth in spite of noteworthy differences between the treatments in terms of initial distance between the planted seedling and the nearest ericaceous shrubs and percent cover of these species. Ericaceous shrubs are known for their adverse effects on conifer nutrition and growth (de Montigny and Weetman 1990; Titus et al. 1995; Thiffault et al. 2004). Despite their higher cover in the scarified versus scalped plots, these species seemed to have influenced main resources very little. This finding was reflected by the almost nil (Fig. 4) or positive (Fig. 5) correlations between ericaceous cover and soil $\mathrm{N}$ concentrations and cation exchange capacity. In addition, the distribution of observations associated with the two treatments in the space defined by the first two principal components did not illustrate strong trends. Although the abundance of ericaceous shrubs was associated with low soil $\mathrm{P}$ concentrations as reported in other studies (e.g., Bloom and Mallik 2006), foliar P concentration in black spruce and jack pine remained relatively independent from the presence of 

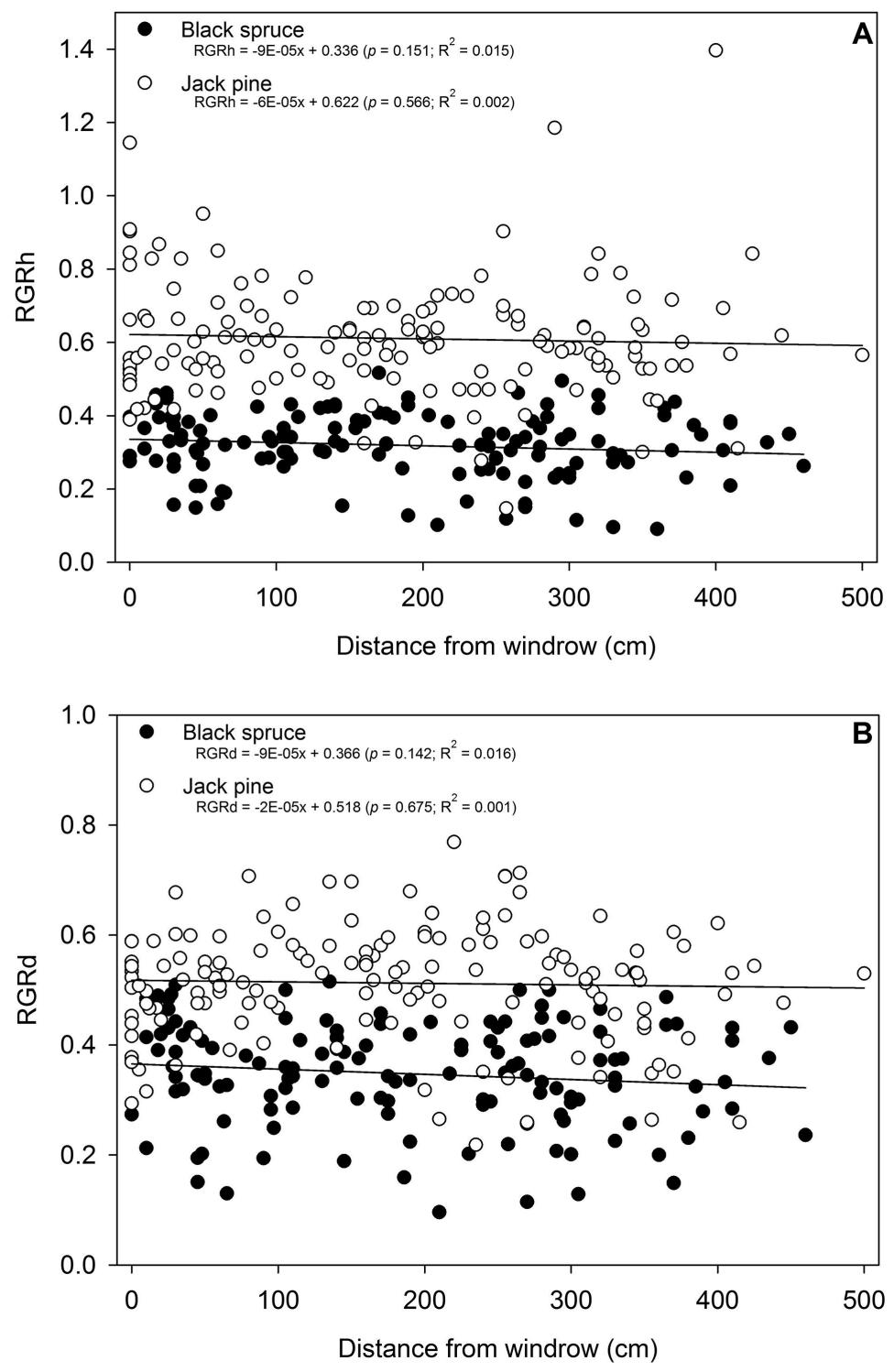

Fig. 3. Relationship between distance from nearest windrow and relative height (RGRh; A) and diameter (RGRd; B) growth rates for seedlings in plots subjected to scalping.

ericaceous shrubs. Trenching typically creates plantation microsites half comprised of exposed mineral soil (Prévost and Thiffault 2013). Such an environment is poorly suited to the vegetative reproduction of Kalmia (Mallik 1993). Therefore, seedlings planted on microsites created by scarification benefited from a growth environment partly free of the influence of ericaceous species, at least for the first three seasons following planting.

Contrary to our predictions, seedling growth in scalped plots did not vary significantly based on the distance from organic matter heaps. This absence of a significant relationship may be due to the relatively low nutritional requirements of conifers (Munson and Timmer 1989), compared with those of species such as Prunus pensylvanica L. (Jobidon 1995) for which such a relation was observed on sites subjected to conventional windrowing, without exporting organic matter (McCavour et al. 2014). In fact, the characteristics of the litter and the cold, humid climate of the boreal forest slow down organic matter mineralization (Van Cleve et al. 1981, Van Cleve et al. 1990, Scott and Binkley 1997, Pajuste and Frey 2003). Therefore, nutrients accumulated in windrows would certainly require several years to be re-circulated (Blumfield et al. 2004). Mid- and long-term monitoring of seedling growth and nutritional status will be required to verify this hypothesis. Over time, seedlings located at the centre of scalped plots (the farthest from the windrows) can be expected to show signs of nutrient deficiency, such as leaf chlorosis and stunted growth or even asymmetric root system development (in an attempt to reach the source of nutrients), compared with seedlings located at the edge of plots (next to the main piles of organic matter).

Deeper planting had a nil or positive effect on seedling growth, which varied based on the combinations of treatments and tree species. While we expected a marked positive effect of planting depth in scalped plots due to major temperature variations associated with humus removal (Heiskanen et al. 2013), this variable had the greatest effect in scarified plots for both black spruce and jack pine. Although significant, the relationship between planting depth and seedling growth was rather low, with a $\mathrm{R}^{2}$ of $9 \%$ in the best of cases (Fig. 2b). This result is in line with those of Paquette et al. (2011), who reported that planting depth did not influence black spruce, white spruce (Picea glauca [Moench.] Voss.) and jack pine growth planted on boreal sites during the first 19 years of growth. Frost heaving issues are generally more prevalent in fine-textured soils because of the frostdefrost cycle (Rempel 2010). Therefore, the coarse textured soil of our study site could explain the low incidence of planting depth on growth.

As expected, jack pine largely outgrew black spruce. This difference probably reflects the intrinsic differences in carbon-fixing capacities between a shade-intolerant (jack pine) and tolerant (black spruce) species (Reich et al. 1998b). The principal component analyses highlighted these differences. Although the relative height growth rate was independent from soil $\mathrm{N}$ concentration and cation exchange capacity for black spruce (at a right angle, respectively along the two first axes; Fig. 4a), the same variables were negatively correlated 

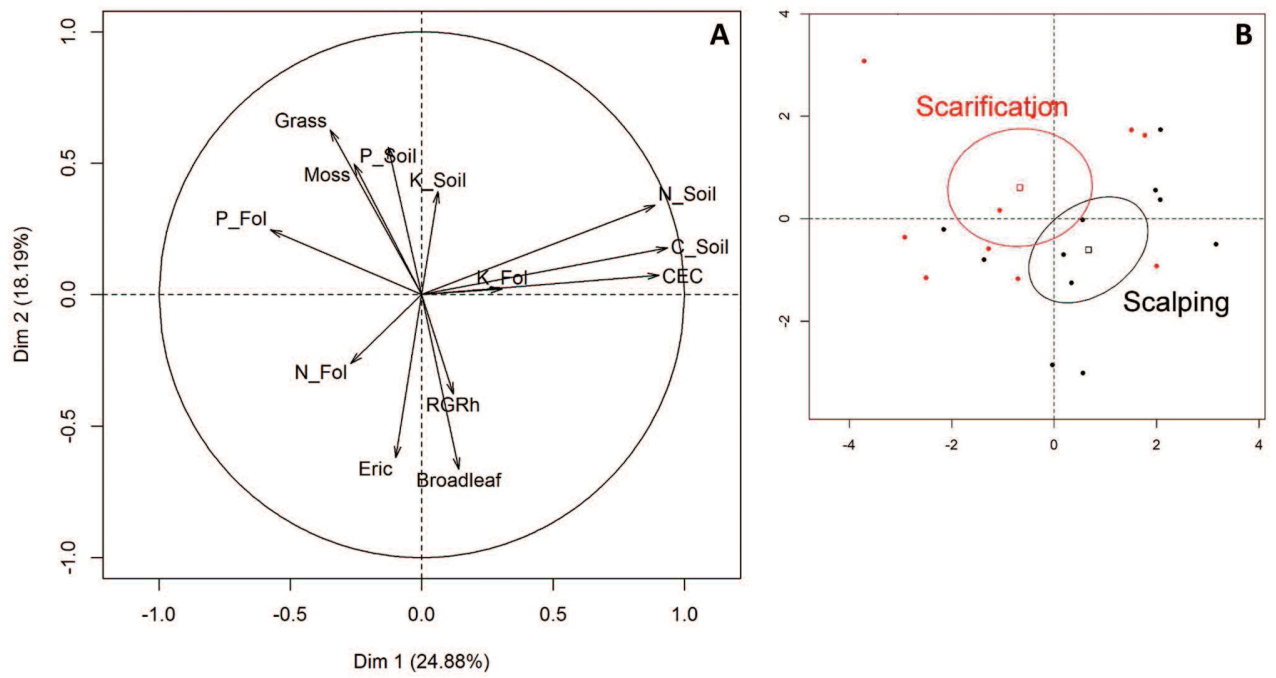

Fig. 4. Principal component analysis illustrating correlations between microsite characteristics, percent cover of main groups of species, and black spruce foliar nutrient concentration and growth (A). N Fol = foliar nitrogen concentration; $P$ Fol = foliar phosphorus concentration; K Fol = foliar potassium concentration; N Soil = soil nitrogen concentration; $P$ Soil = soil phosphorus concentration; $\mathrm{K}$ Soil = soil potassium concentration; C Soil = soil carbon concentration; CEC = cation exchange capacity; RGRh = Relative growth rate in height over three growing seasons. B illustrates the distribution of observations associated with scalping and scarification in the space defined by the two first axes. The ellipses represent the $95 \%$ confidence intervals around the averages of the two treatments.
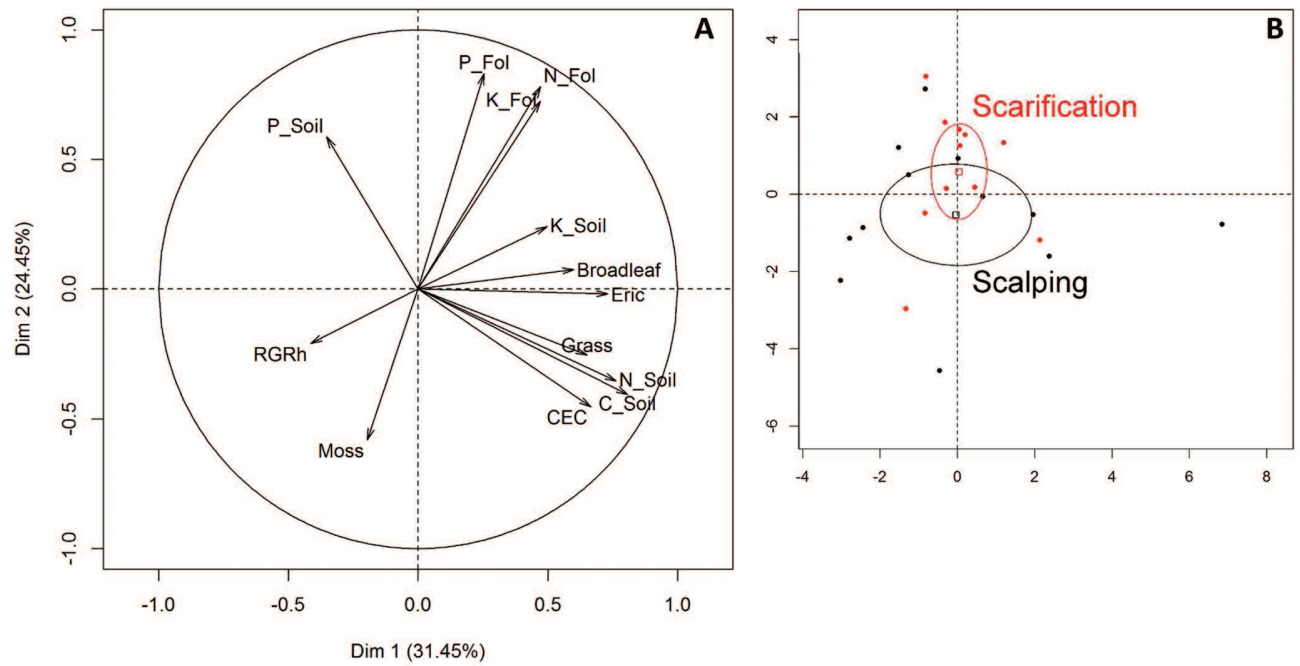

Fig. 5. Principal component analysis illustrating correlations between microsite characteristics, percent cover of main groups of species, and jack pine foliar nutrient concentration and growth (A). N Fol = foliar nitrogen concentration; $P$ Fol = foliar phosphorus concentration; $\mathrm{K} \mathrm{Fol}=$ foliar potassium concentration; $\mathrm{N}$ Soil = soil nitrogen concentration; $\mathrm{P}$ Soil $=$ soil phosphorus concentration; $\mathrm{K}$ Soil $=$ soil potassium concentration; C Soil = soil carbon concentration; CEC = cation exchange capacity; RGRh = Relative growth rate in height over three growing seasons. B illustrates the distribution of observations associated with scalping and scarification in the space defined by the two first axes. The ellipses represent the 95\% confidence intervals around the averages of the two treatments 
for jack pine (in opposite directions along the first axis; Fig. 5b). In addition, the higher foliar nutrient concentrations in black spruce illustrate the ability of this species to adapt and store nutrients in depleted environments (Hom and Oechel 1983, Díaz et al. 2004). In contrast, jack pine is adapted to respond rapidly to the fluctuation of available resources (Díaz et al. 2004). However, foliar nutrient concentration does not completely shed light on the nutritional status of the seedlings because of a potential dilution effect (Timmer 1991). Considering leaf mass might have provided a more complete picture of seedling response in this regard.

For boreal sites with thick humus and dominated by ericaceous shrubs, the short-term results of our study show that the complete removal of organic matter through scalping supports the establishment and initial growth of conifer seedlings without significant differences from trenching. On the short term, the effects of scalping on seedling nutrition and growth can be however, masked by the residual effect of nutrients exported from the nursery in the peat root plug (Idris et al. 2004). The independence between measured soil and needle nutrient concentrations (Fig. 4a and Fig. 5a) illustrates decoupling between the nutritional resources availability and the nutritional status of the seedlings during the first years following planting. Therefore, these results after three years should be interpreted with caution, given the potential mid- and long-term effects of the exportation of organic matter associated with scalping. Indeed, forest humus is a major nutrient capital that should be maintained on sites to guarantee their long-term productivity (Prescott et al. 2000). Over the midand long-term, the accumulation of organic matter in the form of linear windrows located several metres away from seedlings may deprive trees located at the centre of plots from sufficient nutrient intake. In addition, the exposure of the mineral soil over large surfaces causes erosion (Merino and Edeso 1999, Merino et al. 2004) and creates a major source of sediments in watercourses (Olarieta et al. 1999), an aspect not measured in our study. Because of this risk, scalping that causes infertile mineral horizons to be exposed is subject to particular environmental monitoring in Quebec (Jetté 2004). However, ericaceous shrubs may invade trenches rapidly in scarified plots, as suggested by the rapidly shortening distance between planted trees and ericaceous shrubs in these plots (Figs. 1a and 1b). If the rate of Rhododendron and Kalmia invasion in scarified microsites remains significant, seedling nutrition and growth may be affected (Thiffault et al. 2005). Therefore, if organic matter scalping yields a significant benefit compared with conventional scarification in terms of plantation growth on sites with thick humus dominated by ericaceous shrubs, the use of this method should be regulated by conditions that restrict its environmental impact.

\section{Acknowledgments}

The author wishes to thank Jacques Carignan, Alexandre Fortin-Pelletier, Evelyne Gaillard and several summer students for the quality of their technical work, along with Luc Hovington and Michel Fortin for helping to plan and carry out this experiment. Special thanks go to Marcel Prévost, Denise Tousignant, Charles Ward, Denis Langlois and two anonymous reviewers whose relevant comments served to improve a preliminary version of this article. Many thanks to Aimée LeBreton for translating the original manuscript into
English. This study is part of Project 142332106 of the Direction de la recherche forestière of the Ministère des Forêts, de la Faune et des Parcs du Québec. The study was partly funded by the Programme de mise en valeur des ressources du milieu forestier Volet I, Expérimentation sylvicole et activités de recherche ou d'acquisition de connaissances.

\section{References}

Bates, D., M. Mächler, B.M. Bolker and S.C. Walker. 2015. Fitting linear mixed-effects models using lme4. J. Stat. Soft. 67(1): 1-48. doi:10.18637/jss.v067.i01.

Bloom, R.G. and A.U. Mallik. 2006. Relationships between ericaceous vegetation and soil nutrient status in a post-fire Kalmia angustifolia-black spruce chronosequence. Plant Soil 289(1-2): 211-226. doi:10.1007/s11104-006-9130-3.

Blumfield, T.J., Z.H. Xu and P.G. Saffigna. 2004. Carbon and nitrogen dynamics under windrowed residues during the establishment phase of a second-rotation hoop pine plantation in subtropical Australia. For. Ecol. Manage. 200(1-3): 279-291. doi:10.1016/ j.foreco.2004.07.008.

Bouchard, M., D. Pothier and S. Gauthier. 2008. Fire return intervals and tree species succession in the North Shore region of eastern Quebec. Can. J. For. Res. 38(6): 1621-1633. doi:10.1139/X07-201.

Bradley, R.L., B.D. Titus and J.W. Fyles. 1997. Nitrogen acquisition and competitive ability of Kalmia angustifolia L., paper birch (Betula papyrifera Marsh.) and black spruce (Picea mariana (Mill.) BSP) seedlings grown on different humus forms. Plant Soil 195(2): 209-220. doi:10.1023/A:1004263716346.

Burdett, A. 1990. Physiological processes in plantation establishment and the development of specifications for forest planting stock. Can. J. For. Res. 20(4): 415-427. doi:10.1139/x90-059.

Carter, M.R. (ed.). 1993. Soil Sampling and Methods of Analysis. Lewis Publishers and CRC Press LLC, Boca Raton, FL.

de Montigny, L.E. and G.F. Weetman. 1990. The effects of ericaceous plants on forest productivity. In The Silvics and Ecology of Boreal Spruce. B.D. Titus, M.B. Lavigne, P.F. Newton and W.J. Meades (eds.). Canadian Forest Service, Forestry Canada, St. John's, Newfoundland. pp. 83-90.

Devine, W.D. and C.A. Harrington. 2007. Influence of harvest residues and vegetation on microsite soil and air temperatures in a young conifer plantation. Agric. For. Meteorol. 145(1-2): 125-138. doi:10.1016/j.agrformet.2007.04.009.

Díaz, S. et al. 2004. The plant traits that drive ecosystems: Evidence from three continents. J. Veg. Sci. 15(3): 295-304. doi:10.1111/ j.1654-1103.2004.tb02266.x.

Dumas, M.T. 2012. Effect of site preparation on Armillaria ostoyae infection and grow of spruce after partial cutting in a Boreal Mixwood Forest. For. Chron. 88(5): 622-625. doi:10.5558/tfc2015-115

Fox, J. and S. Weisberg. 2011. An R Companion to Applied Regression, Second Edition. Sage Publications.

Frey, B.R., V.J. Lieffers, A.D. Munson and P.V. Blenis. 2003. The influence of partial harvesting and forest floor disturbance on nutrient availability and understory vegetation in boreal mixedwoods. Can. J. For. Res. 33(7): 1180-1188. doi:10.1139/x03-042

Gauthier, S., M.-A. Vaillancourt, A. Leduc, L.D. Grandpré, D. Kneeshaw, H. Morin, P. Drapeau and Y. Bergeron (eds). 2008. Aménagement écosystémique en forêt boréale. Presses de l'Université du Québec, Québec, QC.

Goulet, F. 2000. Frost heaving of planted tree seedlings in the boreal forest of Northern Sweden. Swedish University of Agricultural Sciences, Department of Silviculture. Reports. 45. Umea, Sweden.

Gradowski, T., D. Sidders, T. Keddy, V.J. Leiffers and S.M. Landhäusser. 2008. Effects of overstory retention and site preparation on growth of planted white spruce seedlings in deciduous and coniferous dominated boreal plains mixedwoods. For. Ecol. Manage. 255(11): 3744-3749. doi:10.1016/j.foreco.2008.03.008. 
Gravel, J., M. Prévost and N. Thiffault. 2015. Le scarifiage. Direction de l'aménagement et de l'environnement forestiers et Direction de la recherche forestière, Ministère des Forêts, de la Faune et des Parcs. Publication DAEF2-067-F-18. Québec, QC.

Greene, D.F. et al. 2007. The reduction of organic-layer depth by wildfire in the North American boreal forest and its effect on tree recruitment by seed. Can. J. For. Res. 37(6): 1012-1023. doi:10.1139/x06-245.

Grossnickle, S.C. 2012. Why seedlings survive: Influence of plant attributes. New For. 43(5-6): 711738. doi:10.1007/s11056-0129336-6.

Hébert, F., J.-F. Boucher, D. Walsh, P. Tremblay, D. Côté and D. Lord. 2014. Black spruce growth and survival in boreal open woodlands 10 years following mechanical site preparation and planting. Forestry 87(2): 277-286. doi:10.1093/forestry/cpt052.

Heiskanen, J., T. Saksa and J. Luoranen. 2013. Soil preparation method affects outplanting success of Norway spruce container seedlings on till soils susceptible to frost heave. Silva Fenn. 47(1): article id 893.

Henneb, M., O. Valeria, N.J. Fenton, N. Thiffault and Y. Bergeron. 2015. Mechanical site preparation: Key to microsite creation success on Clay Belt paludified sites. For. Chron. 91(2): 187-196. doi:10.5558/tfc2015-030.

Hom, J.L. and W.C. Oechel. 1983. The photosynthetic capacity, nutrient content and nutrient use efficiency of different needle age classes of black spruce (Picea mariana) found in interior Alaska, USA. Can. J. For. Res. 13(5): 834-839. doi:10.1139/x83-113.

Idris, M., K.F. Salifu and V.R. Timmer. 2004. Root plug effects on early growth and nutrition of container black spruce seedlings. For. Ecol. Manage. 195(3): 399-408. doi:10.1016/j.foreco.2004.03.005.

Inderjit and A.U. Mallik. 1999. Nutrient status of black spruce (Picea mariana [Mill.] BSP) forest soils dominated by Kalmia angustifolia L. Acta Oecol. 20(2): 87-92. doi:10.1016/S1146-609X (99)80020-4.

Jetté, J.-P. 2004. Protéger les sols forestiers par une approche de gestion adaptative. Nat. Can. 128(2): 78-84.

Jobidon, R. 1995. Autécologie de quelques espèces de compétition d'importance pour la régénération forestière au Québec. Revue de littérature. Direction de la forestière, Ministère des Ressources naturelles. Mémoire de recherche forestière 117. Québec. QC.

Lazaruk, L.W., S.E. Macdonald and G. Kernaghan. 2008. The effect of mechnical site preparation on ectomycorrhizae of planted white spruce seedlings in conifer-dominated boreal mixedwood forest. Can. J. For. Res. 38(7): 2072-2079. doi:10.1139/x08-035.

Lê, S., J. Josse and F. Husson. 2008. FactoMineR: An R package for multivariate analysis. J. Stat. Softw. 25(1): 118. doi:10.18637/ jss.v025.i01.

LeBel, P., N. Thiffault and R.L. Bradley. 2008. Kalmia removal increases nutrient supply and growth of black spruce seedlings: An effect fertilizer cannot emulate. For. Ecol. Manage. 256(10): 1780-1784. doi:10.1016/j.foreco.2008.02.050.

Lieffers, V.J., C. Messier, P.J. Burton, J.-C. Ruel and B.E. Grover. 2003. Nature-based silviculture for sustaining a variety of boreal forest values. In Towards Sustainable Management of the Boreal Forest. P. J. Burton, C. Messier, D.W. Smith and W.L. Adamowicz (eds.). NRC Research Press, Ottawa, ON. pp. 481-530.

Mallik, A.U. 1993. Ecology of a forest weed of Newfoundland: vegetative regeneration strategy of Kalmia angustifolia. Can. J. Bot. 71(1): 161-166. doi:10.1139/b93-018.

Margolis, H.A. and D.G. Brand. 1990. An ecophysiological basis for understanding plantation establishement. Can. J. For. Res. 20(4): 375-390. doi:10.1139/X90-056.

McCavour, M.J., D. Paré, C. Messier, N. Thiffault and E. Thiffault. 2014. The role of aggregated forest harvest residue in soil fertility, plant growth, and pollination services. Soil Sci. Soc. Am. J. 78(S1): S196-S207. doi:10.2136/sssaj2013.08.0373nafsc.
Merino, A. and J.M. Edeso. 1999. Soil fertility rehabilitation in young Pinus radiata D. Don. plantations from northern Spain after intensive site preparation. For. Ecol. Manage. 116(1-3): 83-91. doi:10.1016/S0378-1127(98)00444-7.

Merino, A., A. Fernández-López, F. Solla-Gullón and J.M. Edeso. 2004. Soil changes and tree growth in intensively managed Pinus radiata in northern Spain. For. Ecol. Manage. 196(2-3): 393-404. doi:10.1016/j.foreco.2004.04.002.

Munson, A.D. and V.R. Timmer. 1989. Site specific growth and nutrition of planted Picea mariana in the Ontario Clay Belt. II. Effects of nitrogen fertilization. Can. J. For. Res. 19(2): 171-178. doi:10.1139/x89-024

Munson, A.D., H.A. Margolis and D.G. Brand. 1993. Intensive silvicultural treatment: Impacts on soil fertility and planted conifer response. Soil Sci. Soc. Am. J. 57(1): 246-255. doi:10.2136/sssaj1993. 03615995005700010043x.

Newmaster, S.G., W.C. Parker, F.W. Bell and J.M. Paterson. 2007. Effects of forest floor disturbances by mechanical site preparation on floristic diversity in a central Ontario clearcut. For. Ecol. Manage. 246(2-3): 196-207. doi:10.1016/foreco.2007.03.058.

Nyland, R.D. 2002. Silviculture: Concepts and Applications. Second Edition. Waveland Press, Inc., Long Grove, Illinois.

Olarieta, J.R., G. Besga, R. Rodríguez, A. Usón, M. Pinto and S. Virgel. 1999. Sediment enrichment ratios after mechanical site preparation for Pinus radiata plantation in the Basque Country. Geoderma 93(3-4): 255-267. doi:10.1016/S0016-7061(99)00063-4.

Pajuste, K. and J. Frey. 2003. Nitrogen mineralisation in podzol soils under boreal Scots pine and Norway spruce stands. Plant Soil 257(1): 237-247. doi:10.1023/A:1026222831694.

Paquette, A., J. Girard and D. Walsh. 2011. Deep planting has no short- or long-term effect on the survival and growth of white spruce, black spruce, and jack pine. North. J. Appl. For. 28(3): 146-151.

Prescott, C.E., D.G. Maynard and R. Laiho. 2000. Humus in northern forests: friend or foe? For. Ecol. Manage. 133(1-2): 23-36. doi:10.1016/S0378-1127(99)00295-9.

Prévost, M. 1992. Effets du scarifiage sur les propriétés du sol, la croissance des semis et la compétition : revue des connaissances actuelles et perspectives de recherches au Québec. Ann. Sci. For. 49(3): 277-296. doi:10.1051/forest:19920306.

Prévost, M. and D. Dumais. 2003. Croissance et statut nutritif de marcottes, de semis naturels et de plants d'épinette noire à la suite du scarifiage : résultats de 10 ans. Can. J. For. Res. 33(1): 2097-2107. doi:10.1139/X03-130.

Prévost, M. and N. Thiffault. 2013. La préparation de terrain. In Le guide sylvicole du Québec. Tome 2. Les concepts et l'application de la sylviculture. C. Larouche, F. Guillemette, P. Raymond and J.-P. Saucier (eds.). Les Publications du Québec, Québec, QC. pp. 134-157. R Core Team. 2013. R: A language and environment for statistical computing. R Foundation for Statistical Computing, Vienna, Austria. Reich, P.B., M.B. Walters, M.G. Tjoelker, D. Vanderklein and C. Buschena. 1998a. Photosynthesis and respiration rates depend on leaf and root morphology and nitrogen concentration in nine boreal tree species differing in relative growth rate. Funct. Ecol. 12(3): 395-405. doi:10.1046/j.1365-2435.1998.00209.x.

Reich, P.B., M.G. Tjoelker, B. Walters, D. Vanderklein and C. Buschena. 1998b. Close association of RGR, leaf and root morphology, seed mass and shade tolerance in seedlings of nine boreal tree species grown in high and low light. Funct. Ecol. 12(3): 327-338. doi:10.1046/j.1365-2435.1998.00208.x.

Rempel, A.W. 2010. Frost heave. J. Glaciol. 56(200): 1122-1128. Sahlén, K. and F. Goulet. 2002. Reduction of frost heaving of Norway spruce and scots pine seedlings by planting in mounds or in humus. New For. 24(3): 175-182. doi:10.1023/A:1021378228524.

Salonius, P.O. 1983. Effects of organic-mineral mixtures and increasing temperature on the respiration of coniferous raw humus material. Can. J. For. Res. 13(1): 102-107. doi:10.1139/x83-015. 
Saucier, J.P., A. Robitaille and P. Grondin. 2009. Cadre bioclimatique du Québec. In Manuel de foresterie, 2nd edition. R. Doucet and M. Côté (eds.). Ordre des ingénieurs forestiers du Québec, Éditions Multimondes, Québec, QC. pp. 186-205.

Scott, N.A. and D. Binkley. 1997. Foliage litter quality and annual net $\mathrm{N}$ mineralization: comparison across North American forest sites. Oecologia 111(2): 151-159. doi:10.1007/s004420050219.

Soil Classification Working Group. 1998. The Canadian System of Soil Classification. 3rd ed. Agriculture and Agri-Food Canada. Publication 1646. Ottawa, ON.

Sutton, R.F. 1995. Advantages of deep planting black spruce. Natural Resources Canada, Canadian Forest Service. Technical Note 50. Sault Ste. Marie, ON.

Thiffault, N. and P. Grondin. 2003. Envahissement des parterres de coupe par les éricacées. In Les enjeux de biodiversité relatifs à la composition forestière, P. Grondin and A. Cimon, coord. Ministère des Ressources naturelles, de la Faune et des Parcs, Direction de la recherche forestière and Direction de l'environnement forestier. Québec, QC.

Thiffault, N. and R. Jobidon. 2006. How to shift unproductive Kalmia angustifolia - Rhododendron groenlandicum heath to productive conifer plantation. Can. J. For. Res. 36(10): 2364-2376. doi: 10.1139/x06-090.

Thiffault, N., B.D. Titus and A.D. Munson. 2004. Black spruce seedlings in a Kalmia-Vaccinium association: microsite manipulation to explore interactions in the field. Can. J. For. Res. 34(8): 1657-1668. doi:10.1139/x04-046.

Thiffault, N., B.D. Titus and A.D. Munson. 2005. Silvicultural options to promote seedling establishment on Kalmia-Vacciniumdominated sites. Scand. J. For. Res. 20(2): 110-121. doi:10.1080/ 02827580510008356.

Thiffault, N., G. Picher and I. Auger. 2012. Initial distance to Kalmia angustifolia as a predictor of planted conifer growth. New For. 43(5-6): 849-868. doi:10.1007/s11056-012-9324-x.

Thiffault, N., V. Roy, J. Ménétrier, G. Prégent and A. Rainville. 2013. La plantation. In Le guide sylvicole du Québec. Tome 2. Les concepts et l'application de la sylviculture. C. Larouche, F. Guillemette, P. Raymond and J.-P. Saucier (eds.), Québec, QC. pp. 196-225.

Thiffault, N., P. Grondin, J. Noël and V. Poirier. 2015. Ecological gradients driving the distribution of four Ericaceae in boreal Quebec, Canada. Ecol. Evol. 5(9): 1837-1853. doi:10.1002/ece3.1476.

Timmer, V.R. 1991. Interpretation of seedling analysis and visual symptoms. In Mineral nutrition of conifer seedlings. R. Van Den Driessche (ed.). CRC Press, Boston, MA. pp. 113-134.

Titus, B.D., S.S. Sidhu and A.U. Mallik. 1995. A summary of some studies on Kalmia angustifolia L.: A problem species in Newfoundland forestry. Natural Resources Canada, Canadian Forest Service. Information Report N-X-296. St-John's, NFL.

Trottier-Picard, A., E. Thiffault, A. DesRochers, D. Paré, N. Thiffault and C. Messier. 2014. Amounts of logging residues affect planting microsites: A manipulative study across northern forest ecosystems. For. Ecol. Manage. 312: 203-215. doi:10.1016/ j.foreco.2013.10.004.

Van Cleve, K., R. Barney and R. Schlentner. 1981. Evidence of temperature control of production and nutrient cycling in two interior Alaska black spruce ecosystems. Can. J. For. Res. 11(2): 259-274. doi:10.1139/x81-035.

Van Cleve, K., W.C. Oechel and J.L. Hom. 1990. Response of black spruce (Picea mariana) ecosystems to soil temperature modification in interior Alaska. Can. J. For. Res. 20(9): 1530-1535. doi:10.1139/ x90-203.

Walinga, I., J.J. van der Lee, V.J.G. Houba, W. van Vark and I. Novozamsky (eds). 1995. Plant Analysis Manual, Dordrecht, The Netherlands.

Ward, C., D. Pothier and D. Paré. 2014. Do boreal forests need fire disturbance to maintain productivity? Ecosystems 17(6): 1053-1067. doi:10.1007/s10021-014-9782-4.

Yee, T.W. 2008. The VGAM Package. R News 8(2): 28-39. 